\title{
Bacterial community dynamics in the hyporheic zone of an intermittent stream
}

\author{
Catherine M Febria ${ }^{1,3}$, Paul Beddoes ${ }^{1,4}$, Roberta R Fulthorpe ${ }^{2}$ and D Dudley Williams ${ }^{1}$ \\ ${ }^{1}$ Surface and Groundwater Ecology Research Group, University of Toronto Scarborough, Toronto, Ontario, \\ Canada and ${ }^{2}$ Department of Physical and Environmental Sciences, University of Toronto Scarborough, \\ Toronto, Ontario, Canada
}

\begin{abstract}
The dynamics of in situ bacterial communities in the hyporheic zone of an intermittent stream were described in high spatiotemporal detail. We assessed community dynamics in stream sediments and interstitial pore water over a two-year period using terminal-restriction fragment length polymorphism. Here, we show that sediments remained saturated despite months of drought and limited hydrologic connectivity. The intermittency of stream surface water affected interstitial pore water communities more than hyporheic sediment communities. Seasonal changes in bacterial community composition was significantly associated with water intermittency, phosphate concentrations, temperature, nitrate and dissolved organic carbon (DOC) concentrations. During periods of low- to no-surface water, communities changed from being rich in operational taxonomic units (OTUs) in isolated surface pools, to a few OTUs overall, including an overall decline in both common and rare taxa. Individual OTUs were compared between porewater and sediments. A total of $19 \%$ of identified OTUs existed in both porewater and sediment samples, suggesting that bacteria use hyporheic sediments as a type of refuge from dessication, transported through hydrologically connected pore spaces. Stream intermittency impacted bacterial diversity on rapid timescales (that is, within days), below-ground and in the hyporheic zone. Owing to the coupling of intermittent streams to the surrounding watershed, we stress the importance of understanding connectivity at the pore scale, consequences for below-ground and above-ground biodiversity and nutrient processing, and across both short- and long-time periods (that is, days to months to years).

The ISME Journal (2012) 6, 1078-1088; doi:10.1038/ismej.2011.173; published online 8 December 2011 Subject Category: microbial ecology and functional diversity of natural habitats

Keywords: hyporheic zone; intermittent streams; bacterial communities; terminal-restriction fragment length polymorphism (T-RFLP); operational taxonomic unit (OTU); stream sediments
\end{abstract}

\section{Introduction}

Watersheds comprise hundreds of small, headwater streams within their boundaries (Naiman et al., 2005), and biodiversity in these streams remains largely underestimated (Meyer et al., 2007). North American headwater streams are first- and secondorder streams along the river continuum (Vannote et al., 1980), small in scale (for example, $<3 \mathrm{~m}$ ), largely fishless and characterized by predictable low-flow conditions (Richardson and Danehy, 2007). Many such streams have intermittent water balances and physicochemical attributes that vary

Correspondence: CM Febria, Chesapeake Biological Laboratory, University of Maryland Center for Environmental Science, 1 Williams Street, PO Box 38, Solomons, MD 20688, USA.

E-mail: febria@umces.edu

${ }^{3}$ Current address: Chesapeake Biological Laboratory, University of Maryland Center for Environmental Science, 1 Williams Street, PO Box 38, Solomons MD 20688, USA.

${ }^{4}$ Current address: Golder and Associates, 500-4260 Still Creek Drive, Burnaby, BC V5C 6C6, Canada.

Received 29 August 2011; revised 10 October 2011; accepted 10 October 2011; published online 8 December 2011 between wet and dry years (Boulton and Lake, 1990; Larned et al., 2010), and support seasonally diverse and intricate food webs (Boulton and Lake, 1992; Closs and Lake, 1994; Dekar et al., 2009). Moreover, rich macroinvertebrate communities inhabit streambed sediments in these small streams, and in particular, the hyporheic zone (Williams, 1984, 1989; Williams, 1993). This zone, a transitional ecotone between surface and groundwater, is characterized by strong gradients in nutrients and hydrologic exchange (Boulton et al., 1998, Williams, 1993; Williams et al., 2010); however, an understanding of its microbial ecology is lacking (Storey et al., 1999). As the lateral boundaries of the zone are both seasonally and spatially dynamic, the hyporheic zone and intermittent streams serve as model systems for studying the relative controls of environmental factors that shape in situ community dynamics.

Descriptions of microbial diversity in lotic systems have been conducted mostly on higher-order streams (Findlay and Sobczak, 2000; Feris et al., 2003; Lowell et al., 2009) while dynamics in intermittent reaches are few. Based on studies in 
more permanent systems, sediment microbial communities have been shown to be: spatially diverse along flowpaths (Lowell et al., 2009), correlated with depth into the sediments (Sliva and Williams, 2005) and seasonal physicochemical parameters (Febria et al., 2010). Key microbial groups have been found to recur each season, and these communities can be tightly coupled with the benthic phototrophs in the surrounding watershed (Hullar et al., 2006). Critical to headwater streams is the degree of hydrologic connectivity between microhabitats as a key mechanism for organismal transport and distribution of nutrients through interstitial pore spaces. When a stream dries up at the surface, hyporheic flowpaths can become disrupted for unpredictable lengths of time. Generally, water intermittency in surface water can alter the lateral reaches and depth of the hyporheic zone, as well as disconnect surface microbial communities from the sediments, leading to patchy distributions of bacterial communities.

Both deterministic and stochastic processes may shape bacterial communities in opposing ways. Larger, more severe periods of flood or drought may support regional colonists from surrounding watershed sources during flood and select for specialists when conditions become unfavourable (that is, determinism), whereas less-severe events are evidence of random, stochastic processes within a watershed. Therefore, hypothetically, we predict that hyporheic bacterial taxa may range in type from generalist to specialist along a gradient of connectivity and patchiness in the hyporheic zone (Figure 1). Disturbance events, such as gradients of surface water flow and cessation, and their impacts on stream biota depend largely on the severity and timing of the event (Lepori and Malmqvist, 2009; Larned et al., 2010) and are becoming increasingly common stressors to perennial streams. In particular, sediment biological communities are affected by flood and drought through the creation of localized wet and dry refugia (Lake, 2000). Few hypotheses

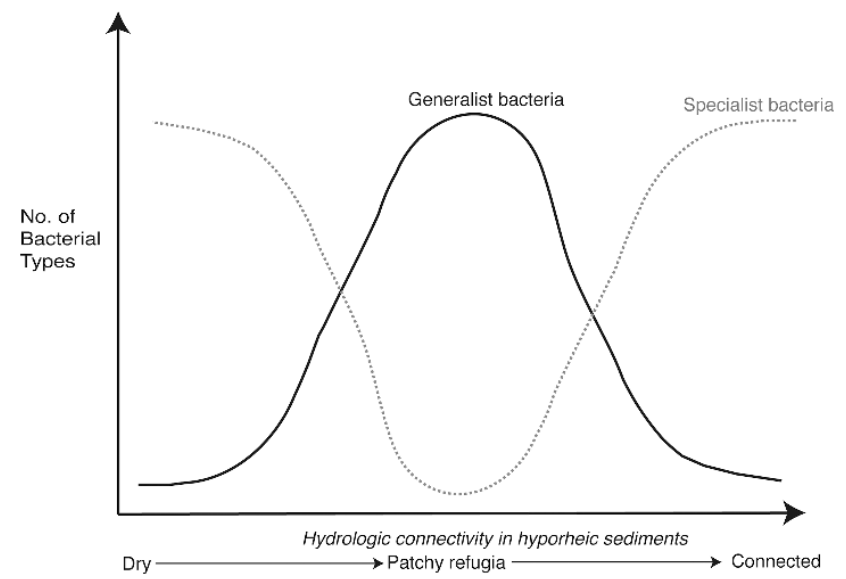

Figure 1 Theoretical relationship between generalist and specialist bacteria in hyporheic sediments and porewater in relation to disturbance. have addressed the consequence of intermittency on hyporheic bacteria, and current theories for larger biota (for example, macroinvertebrates) do not apply to bacteria and other microbes. The hyporheic refuge hypothesis, for example, first proposed by Williams and Hynes (1974) and tested by others (Brunke and Gonser, 1997; Fowler and Death, 2001; DiStefano et al., 2009), predicted that macroinvertebrate biota migrate deeper into streambed sediments when conditions on the stream surface become unfavourable. For microbial communities, such a theory requires revising as the physical factors influencing their assembly and distribution are different.

To begin addressing the existing knowledge gaps, we first described the spatiotemporal patterns of in situ bacterial communities across consecutive seasons-during a year with little to no-surface water flow, followed by a year of high surface water flow. We used multivariate statistics to test how these communities correlate with measured physicochemical parameters. As bacteria are carried through interstitial pores associated with regional hydrological events, we predicted that sediment bacterial communities would be similar and less variable than bacterial communities from surface and interstitial water. Here, we show how temporal changes in bacterial communities differed over short- and long-time scales (that is, days to weeks to years) and sought to understand the distribution of bacterial taxa across varying spatial and temporal gradients. The present study represents the first to describe in situ bacterial community dynamics in both the porewater and sediments of an intermittent headwater stream. We show how communities correlate to local environmental factors and also demonstrate how high inter-annual variability can lead to considerable changes in community composition. These results may have biodiversity and biogeochemical implications for other headwater streams where increased development, land-use and climate change scenarios predict changes to the hydrologic balance, and a shift in permanent streams becoming more intermittent over time.

\section{Methods}

Study site and sample collection

The Dewar intermittent stream is a tributary of the Speed River in southern Ontario, Canada $\left(43^{\circ} 42^{\prime} \mathrm{N}\right.$, $80^{\circ} 17^{\prime} \mathrm{W}$ ). This stream section studied was no more than $2 \mathrm{~m}$ in width when flooded. To a depth of $1.1 \mathrm{~m}$, the streambed sediments consisted of fine silts and very fine sands (that is, $<1 \mathrm{~mm}$ ). The riparian area, populated by deciduous trees (Betula sp., Acer sp.) and a few conifers (Thuja sp.), provided dense forest cover over the stream during the spring, summer and early fall months. Over the course of the study, the stream and streambed sediments varied between being flooded, partially flooded and dry (Figure 2). Stream surface water intermittency was categorized into stages of hydrological connection. 'Flooding' 

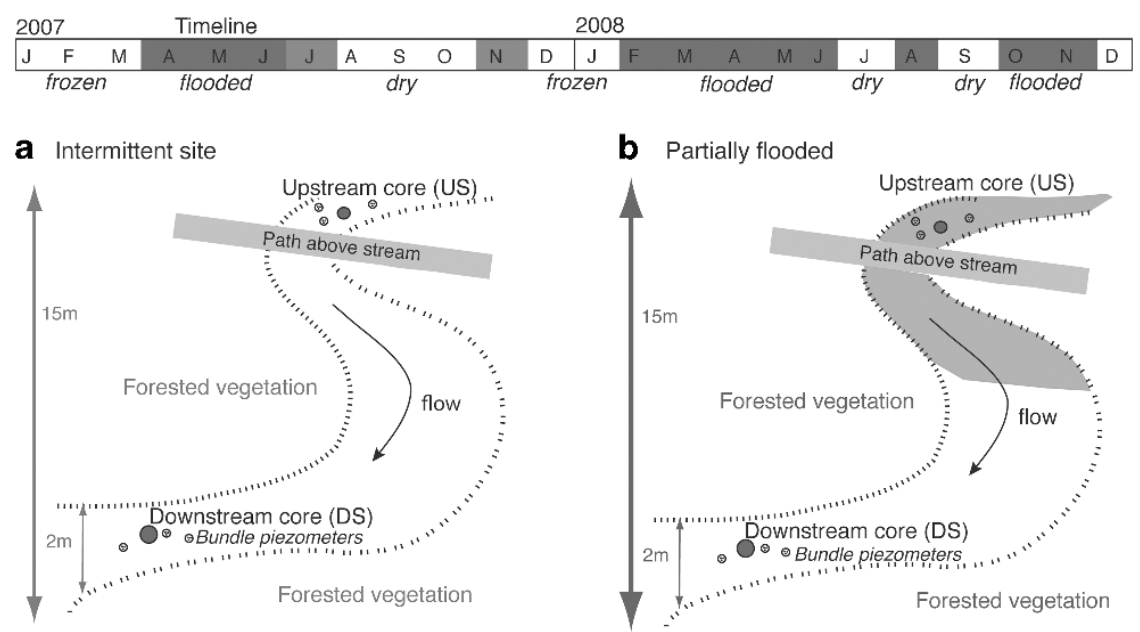

Figure 2 Plan view of the intermittent stream, site instrumentation and flooding dynamics between 2007 and 2008 . Panel above the schematic outlines the general timeline when the streambed was flooded (a, dark grey bars), partially flooded (b, in green, also indicated as green bars in the timeline) and when dry (white bars in the timeline). Shading indicates approximate extent of surface water during flooded, partially flooded and dry conditions (dates provided to the right of each panel). US site, upstream location of the colonization corer; DS site, downstream location of the colonization corer. Also shown are the approximate locations of bundle piezometers at each US and DS site (three-bundle piezometers each at 20,60 and $100 \mathrm{~cm}$ depths). The color reproduction of this figure is available at the The ISME Journal online.

described when the stream surface was hydrologically connected (that is, flowing), and 'drought' described when the streambed was effectively dry (that is, surface water gone or present in isolated pools). Sediment and interstitial water were collected using steel colonization corers and attached piezometers (Figure 3, Supplementary Photo 1). The corers were installed $\sim 15 \mathrm{~m}$ apart in an upstream (US) and downstream (DS) location. Briefly, each steel sampling core held a plexiglass inner sleeve for colonization. Each inner sleeve, $\sim 1.1 \mathrm{~m}$ in length, consisted of $20-\mathrm{cm}$ sections, separated by polyvinyl chloride dividers $2 \mathrm{~cm}$ in diameter. Each section and the corer itself were perforated with holes to allow for interstitial flow and colonization by microbes. Previously collected natural sediment was sterilized and placed within the colonization sleeve at 20,60 and $100 \mathrm{~cm}$ depths. The corers were left at the site to allow colonization by microbes and the sediment was replaced monthly.

We sampled the stream for most months in 2007 and 2008. When sufficient interstitial porewater was present, samples were collected for water chemistry analyses. Water samples were not collected if piezometers were frozen during winter months or if specific depths were dry during the summer, for example. A network of three-bundle piezometers, each within $1 \mathrm{~m}$ of the colonization corer, was installed to increase the yield of hyporheic water collected, especially when surface flow ceased and the water table was low. Totals of up to $500 \mathrm{ml}$ of water samples were collected, placed in clean highdensity polyethylene bottles, and transported back to the laboratory for DNA extraction and further analyses. Sediment samples were frozen at $-20^{\circ} \mathrm{C}$ to await DNA analysis.

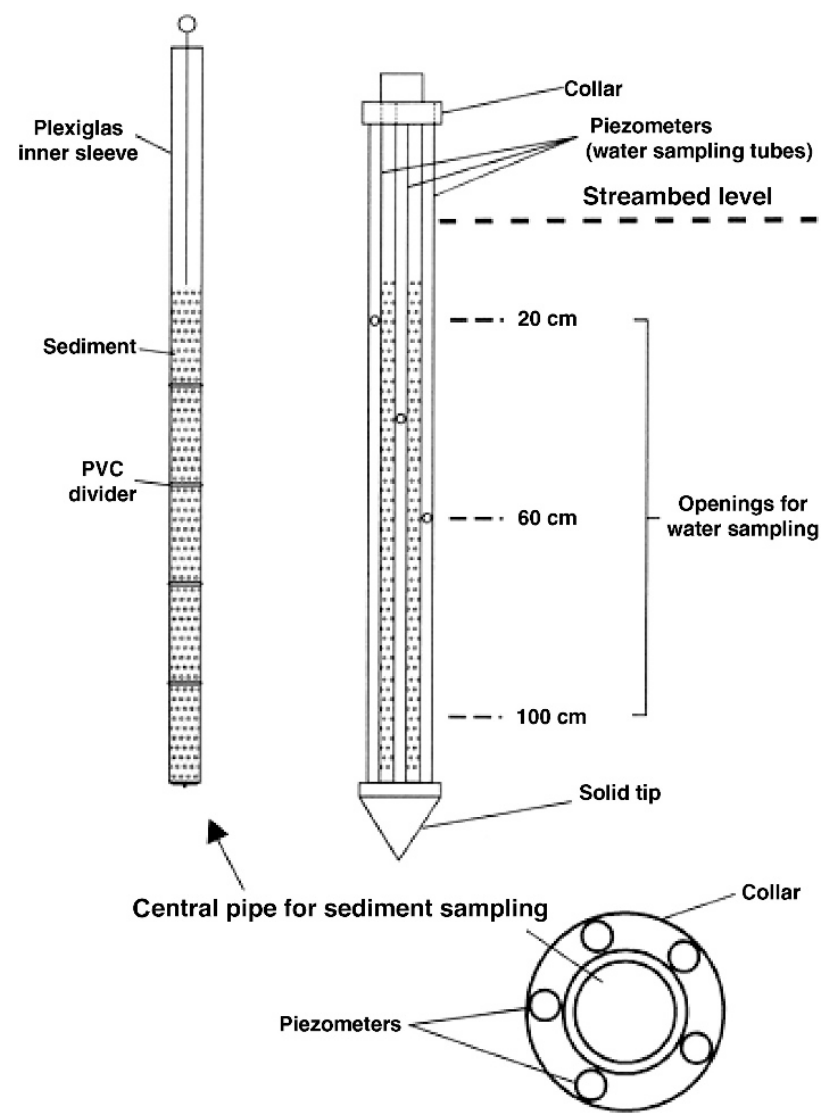

Figure 3 Details of the standpipe colonization corer installed at the US and DS sites. Locations are indicated in Figure 1. Shown is the steel corer with fused piezometers on the outer perimeter of the corer (also shown in plan view). Piezometers allowed for interstitial water sampling at 20,60 and $100 \mathrm{~cm}$ depths. Also pictured is the plexiglass inner sleeve with PVC dividers used to hold autoclaved sediment for bacterial colonization at 20,60 and $100 \mathrm{~cm}$ depths. 
Water chemistry analyses

Temperature, dissolved oxygen saturation (that is, percent saturation, DO\%), pH, total dissolved solids and specific conductivity were measured immediately upon sampling using the Hydrolab all-in-one Quanta Probe (Hach Inc., Loveland, CO, USA). Water and sediment samples were collected and transported immediately to the lab. In the lab, water samples were filtered immediately and measured for nitrate-nitrogen and reactive orthophosphate concentrations (HACH Spectrophotometer, Model 8200) and dissolved organic carbon and total nitrogen concentrations (Shimadzu TOC-V analyzer, Shimadzu Scientific Instruments, Kyoto, Japan).

\section{DNA extraction from sediment and interstitial} porewater samples

DNA was extracted from $1 \mathrm{~g}$ of stream sediment using PowerSoil DNA extraction kits (MoBio Laboratories, Carlsbad, CA, USA) and following the manufacturer's protocol. DNA was extracted from interstitial porewater samples through staged filtration, and DNA was extracted from the filters. Specifically, interstitial porewater samples were left standing for several minutes to allow large particles to settle out. Samples were then syringe-filtered through stacked Swinnex-25 filter cartridges that held a GF/C $1.2 \mu \mathrm{m}$, a Millipore Corp. (Billerica, MA, USA) DAWG $0.65 \mu \mathrm{m}$ (or Millipore Corp., DAWP $0.65 \mu \mathrm{m}$ ) and then a Millipore Corp., Durapore $0.22 \mu \mathrm{m}$ filter, respectively. Approximately, $100 \mathrm{ml}$ of sample water was filtered through each filter stack and the 0.65 and $0.22-\mu \mathrm{m}$ filters were frozen in glass scintillation vials. Immediately before extraction, filters were cut into pieces using sterile techniques, and transferred directly to the prep tubes for DNA extraction. DNA was extracted from the filters using the FastDNA Spin Kit for Soil (MP Biomedicals, La Jolla, CA, USA) and following the manufacturer's protocol. Genomic DNA was verified on a $0.8 \%$ agarose gel stained with ethidium bromide. The extracted DNA samples were kept at $-20{ }^{\circ} \mathrm{C}$ until used for PCR applications.

Bacterial community characterization using terminalrestriction fragment length polymorphism (T-RFLP) Bacterial 16S rRNA gene sequences were amplified using universal bacterial primers 27F (5'-AGA GTT TGA TYM TGG CTC AG-3'; with phosphoramidite dye 6-FAM on the $5^{\prime}$ end; Invitrogen Canada Inc., Burlington, ON, Canada) and 1492R (5'-TAC CTT GTT ACG ACT T-3'; Sigma Genosys, Oakville, ON, Canada). Fifty microlitre reactions were incubated on a PTC-100 thermal cycler (MJ Research Inc., Waltham, MA, USA) using the following parameters: HotStarTaq DNA polymerase initialization at $95{ }^{\circ} \mathrm{C}$ for $5 \mathrm{~min}$, followed by 33 cycles of denaturation at $94^{\circ} \mathrm{C}$ for $1 \mathrm{~min}$, annealing at $55^{\circ} \mathrm{C}$ for $1 \mathrm{~min}$, and extension at $72{ }^{\circ} \mathrm{C}$ for $1 \mathrm{~min}$ and a final extension step at $72{ }^{\circ} \mathrm{C}$ for $10 \mathrm{~min}$. The resultant PCR products were visualized on a 1\% (wt/vol) agarose gel stained with ethidium bromide and quantified using a DNA ladder (GeneRuler $1 \mathrm{~kb}$ DNA Ladder Plus, Fermentas, Burlington, ON, Canada). PCR products were digested at $37^{\circ} \mathrm{C}$ for up to $2 \mathrm{~h}$ using restriction enzymes $M s p I$ and HhaI (New England Biolabs Inc., Ipswich, MA, USA) and visualized on a $3 \%$ (wt/vol) agarose gel stained with ethidium bromide. Digested samples were analyzed on a 3730 DNA sequencer (Applied Biosystems Inc., Fredmont, CA, USA) for sizes and intensities (peak area) of the $5^{\prime}$-terminal fragment at the Laboratory Services Division at the University of Guelph (Guelph, ON, Canada).

\section{Multivariate statistics}

The complete dataset included: physicochemistry for months between 2007 and 2008 when sufficient porewater was collected for analysis $(n=70)$, sediment samples for most months between 2007 and $2008(n=65)$ and interstitial porewater samples during the flooding event $(n=30)$, and a dataset for all samples that included environmental site characteristics such as flooding (presence or absence), season and site depth $(n=95)$. T-RFLP data were graphically displayed as individual fluorescence peaks that represent individual operational taxonomic units (OTU, a proxy for bacterial species). Integrated peak information for each individual OTU was normalized by the total fluorescence. The normalized dataset was exported to other statistical software programs for subsequent calculations and multivariate analyses. To analyze seasonal patterns in the community, monthly sediment samples were pooled into an individual season as follows: winter (December, January and February), spring (March, April and May), summer (June, July and August) and fall (September, October and November). Multi-way analyses of variance (ANOVA) were conducted to test for significant interactions between physicochemical parameters and season, flooding and site. All analyses were conducted with an alpha level of 0.05. Molecular analyses of these samples were limited by time and cost. Though the sampling points were limited to two locations, the sampling frequency (that is, daily to monthly over a 2-year period) and resolution at which samples were collected (that is, $20-\mathrm{cm}$ intervals into the sediment) ensured that the potential for pseudoreplication was reduced.

Bacterial community fingerprints were analyzed using non-metric multidimensional scaling and a Bray-Curtis distance matrix. Non-metric multidimensional scaling is an ordination method for T-RFLP community data that preserves the rank ordering of original distances among observations, and uses these ranks to map the objects in multidimensional ordination space (Gotelli and Ellison, 2004; McCune et al., 2002; Ramette, 2007). To test for significance among groups, an analysis of similarity (ANOSIM) was conducted on all bacterial 
community data, using 999 permutations and a Bray distance measure. Groupings by season, site and flooding were tested, with global $\mathrm{R}$ values providing an indication of separation. Generally, $R>0.5$ indicated good separation, and $R \sim 0$ indicated no separation between groups (Ramette 2007).

In the environmental dataset, binary assignments were made for the presence and absence of surface water at the time of collection. The relationships between physicochemistry and sediment bacterial community data were then tested in two different canonical correlation analyses (CCA) and Monte Carlo permutation test (999 permutations). The first CCA tested constrained the complete bacteria community dataset (porewater and sediment bacteria) by general site characteristics (flooding, season and site depth). The second CCA constrained the subset of sediment bacterial community data for dates where physicochemical data were available (that is, flooded dates only, nine variables in total: temperature, dissolved oxygen, $\mathrm{pH}$, specific conductivity, total dissolved solids, nitrate concentration, phosphate concentration, total nitrogen concentration and dissolved organic carbon concentration). For the porewater bacterial communities, multiple regressions were used to explore relationships between bacterial OTU number and physicochemistry. All analyses were carried out using R Statistical Software for Macintosh (version 2.6.1) and the community ecology package vegan (Oksanen et al., 2009).

\section{Results}

Physicochemistry

The Dewar stream ran dry at the surface early in 2007 until the late-fall and winter. In contrast, in 2008, the site experienced record-level rainfall (that is, 324-mm total precipitation in 2007, 1868-mm total precipitation in 2008, University of Guelph weather records). The narrow US site tended to hold water longer than DS sites where the stream channel widened considerably. While all depths tended to hold water at the US sites, the DS Surface and DS20 locations were frequently dry. The sediments themselves-in the hyporheic zone and most of the streambed-did not dry completely at any point during our sampling and it is recognized that groundwater was present (though not measured directly). Generally, the surface and sediment sites exhibited similar physicochemical trends (Figure 4). Most parameters-temperature, $\mathrm{pH}, \mathrm{DO} \%$, conductivity, nitrate and total nitrogen-were significantly different across season (ANOVA, Table 1). All physicochemical measurements varied significantly between stream surface flooding and drought events. Temperature, $\mathrm{pH}, \mathrm{DO} \%$, conductivity and total dissolved solids varied significantly across the sampling locations ('Site' in Table 1). Several physicochemical parameters exhibited significant interactions between season, site and flooding. A majority of the variation in the physicochemical data was summarized in two principal components (59\%, Figure 5). Total dissolved solids and conductivity represented most of the variation associated on PC1 (high-positive loadings). Temperature and dissolved organic carbon (DOC) were large, highly positive factors on PC2. Several of the sites separate out by season, including fall communities and few summer communities with DOC and total nitrogen. Most summer sites were highly associated with temperature and $\mathrm{pH}$. Fall sites in the dry year (2007) were positively associated with elevated levels of phosphate and dissolved oxygen.

\section{Comparison of OTUs in sediment and interstitial porewater samples}

Interstitial porewater sampling occurred $\sim 1$ week before the stream became flooded at the surface (10 July). The stream became disconnected at the DS site first, with an isolated water pocket at the US site (11 October). A total of 211 unique OTUs were identified with between 1 and 46 OTUs present within each sample, with an average of 7.5 in sediment and 9.9 in water, though not statistically significant. Of the unique OTUs described in our study, 41 were common between the sediment and porewater samples (that is, $19 \%$ of all OTUs). In total, 15 unique OTUs represented $>5 \%$ of the total community in an individual sediment sample. Therefore, most OTUs were present at very low abundances, especially among porewater samples. Of the porewater samples, only six OTUs represented $>5 \%$ of the total community in an individual sample.

\section{Sediment bacterial community composition dynamics} in a drought and wet year

When the stream was connected, sediment bacterial communities resembled each other across multiple sites and seasons. When disconnected (that is, 2007), bacterial communities varied in relation to season. Although US surface sites varied more than DS surface sites, this relationship was not statistically significant. Bacterial community composition was significantly different between sample type, and with season (ANOSIM, groupings by sample type, $R=0.50, P=0.001$; groupings by season, $R=0.06, P=0.019$ ). Considering sediment samples only, bacterial communities in 2007 were more variable than bacterial communities in 2008 (Figure 6). In 2007 (the dry year), most summer communities clustered apart from the fall communities. Only a few of the fall 2007 communities overlapped with 2008 communities, suggesting that bacterial communities were different between years, and possibly in relation to disturbance. Most sediment bacterial communities from 2008 were clustered closely, often overlapping, indicating 

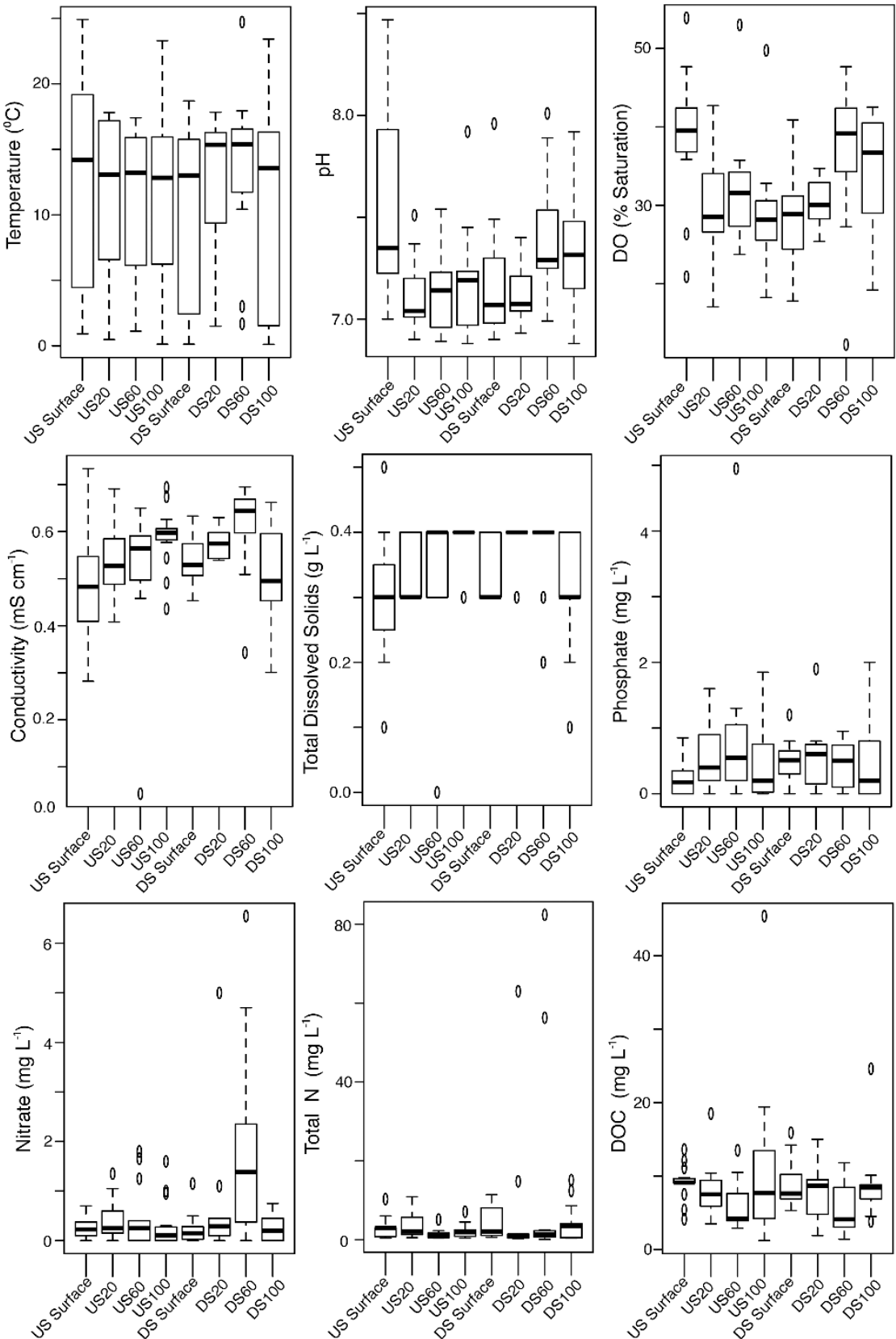

Figure 4 Mean annual values for physicochemistry across the various depths in the hyporheic zone in this study. 20, 60 and $100 \mathrm{~cm}=$ depths in $\mathrm{cm}$ into the streambed sediment. Boxes represent the interquartile range, mean values are indicated by the black line, whiskers show the 10th and 90th percentiles, and individual outliers are shown as circles.

that communities were quite similar. Fall 2008 communities were the most similar in composition, followed by spring and summer 2008 .

Through two separate CCAs, the relationships between site variables and physicochemistry were significant drivers of bacterial community composition, respectively (Figure 7a, Monte Carlo test, 999 permutations, $F=1.26, P<0.01)$. In the first CCA, flooding was significantly associated with most 2008 bacterial communities (the wet year), season was a significant correlate for most fall 2007 communities, followed by site (that is, location and depth) with most spring 2008 communities.
The data were adequately summarized within the first two components (88.0\%). Flooding loaded positively on the first CCA axis and season loaded highest on CCA axis 2. Species sorted mostly by season, particularly among 2007 communities, whereas most communities during the wet year (2008) correlated with flooding and showed little discrimination with season. The second CCA provided complementary insight into the relationships between porewater physicochemistry and sediment bacterial communities. Most communities were associated with DOC or phosphate with little separation between years or seasons (Figure 7b, 
Table 1 Results of multi-way analysis of variance for physicochemical data in relation to site, season and flooding

\begin{tabular}{|c|c|c|c|c|c|c|c|c|c|c|c|c|c|c|c|c|c|c|}
\hline \multirow[b]{2}{*}{ Factor } & \multicolumn{2}{|c|}{ Temperature } & \multicolumn{2}{|l|}{$p H$} & \multicolumn{2}{|c|}{$D O(\%)$} & \multicolumn{2}{|c|}{ Conductivity } & \multicolumn{2}{|c|}{$T D S$} & \multicolumn{2}{|c|}{ Phosphate } & \multicolumn{2}{|c|}{ Nitrate } & \multicolumn{2}{|c|}{ Total N } & \multicolumn{2}{|c|}{$D O C$} \\
\hline & $\mathrm{F}$ & $\mathrm{P}$ & $\mathrm{F}$ & $\mathrm{P}$ & $\mathrm{F}$ & $\mathrm{P}$ & $\mathrm{F}$ & $\mathrm{P}$ & $\mathrm{F}$ & $\mathrm{P}$ & $\mathrm{F}$ & $\mathrm{P}$ & $\mathrm{F}$ & $\mathrm{P}$ & $\mathrm{F}$ & $\mathrm{P}$ & $\mathrm{F}$ & $\mathrm{P}$ \\
\hline Season & 57.02 & $* * *$ & 600.19 & $* * *$ & 28.17 & $* * *$ & 4.23 & * & 0.68 & NS & 0.22 & NS & 8.75 & ** & 25.25 & $* * *$ & 0.18 & NS \\
\hline Site & 5.72 & * & 460.67 & $* * *$ & 10.20 & $* *$ & 10.99 & $* *$ & 9.88 & $* *$ & 0.21 & NS & 2.36 & NS & 2.74 & NS & 0.53 & NS \\
\hline Flooding & 356.45 & $* * *$ & 30741.07 & $* * *$ & 452.50 & $* * *$ & 1567.21 & $* * *$ & 1179.87 & $* * *$ & 30.79 & $* * *$ & 15.95 & $* * *$ & 5.86 & $*$ & 6.28 & $*$ \\
\hline Season*Site & 0.17 & NS & 0.00 & NS & 0.01 & NS & 0.29 & NS & 0.23 & NS & 2.43 & NS & 7.56 & $* * *$ & 6.81 & $* *$ & 0.36 & NS \\
\hline Season*Flooding & 41.51 & $* * *$ & 4.25 & $*$ & 3.14 & NS & 3.13 & NS & 4.27 & $*$ & 0.02 & NS & 7.56 & $* *$ & 10.49 & $* *$ & 0.02 & NS \\
\hline Site ${ }^{*}$ Flooding & 0.16 & NS & 0.17 & NS & 0.34 & NS & 1.15 & NS & 0.44 & NS & 0.13 & NS & 0.19 & NS & 0.14 & NS & 0.87 & NS \\
\hline Season* Site*Flooding & 0.71 & NS & 0.00 & NS & 0.09 & NS & 0.00 & NS & 0.00 & NS & 0.70 & NS & 2.17 & NS & 2.39 & NS & 0.20 & NS \\
\hline
\end{tabular}

Abbreviations: DOC, dissolved organic carbon; NS, not significant; TDS, total dissolved solids.

$P>0.05 ;{ }^{*} P<0.05 ;{ }^{*} P<0.01 ;{ }^{*}{ }^{*} P<0.001$. See Figure 4 for units of measurement.

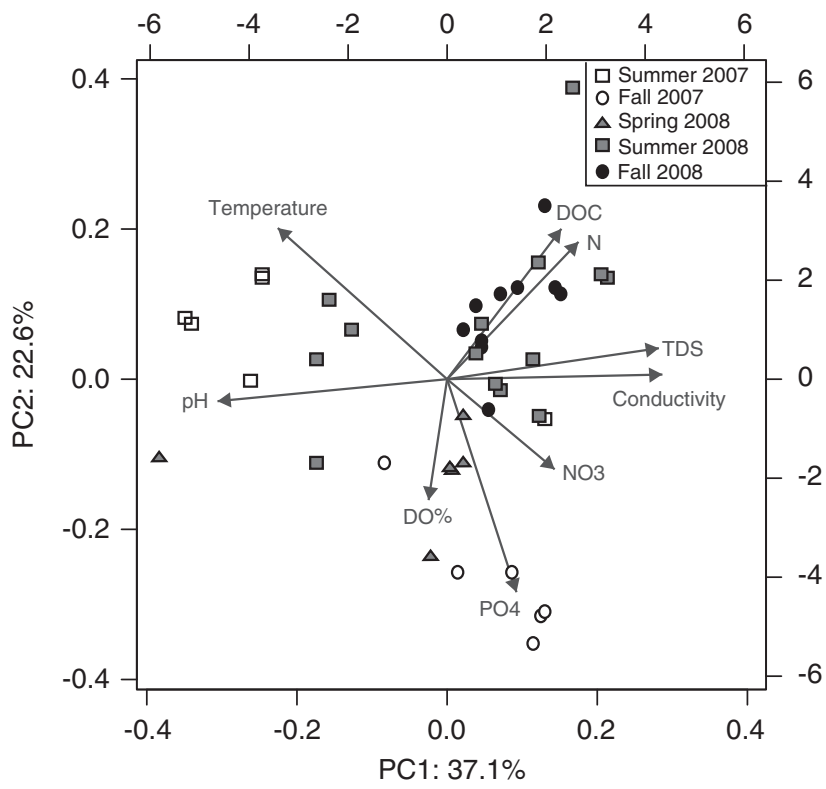

Figure 5 Biplot of principal component analysis conducted for all sampling dates at the Dewar stream site. Arrows indicate direction and magnitude of loadings on the first principal component. Each point represents an individual site, location and date. Similar direction and magnitude of arrows indicate a high-positive association. Indicated are measurements taken during the following seasons: Summer 2007 (white squares), Fall 2007 (white circles), Spring 2008 (grey triangles), Summer 2008 (grey squares) and Fall 2008 (black circles).

Monte Carlo test, 999 permutations, $F=1.34$, $P<0.05)$. Most of the variation was explained within the first three CCA components (56.6\%). The largest drivers here were phosphate concentrations (highest loading on CCA axis 1) and nitrate concentrations (highest loading on CCA axis 2). Several other parameters-temperature, $\mathrm{pH}$, total dissolved solids and conductivity-loaded highly on CCA2. These results showed some discrimination with season, mostly notably among fall 2007 samples, which were highly correlated with phosphate concentrations. Covariables including flooding, season and physicochemistry including DOC and phosphate concentrates were significant correlates with both sediment and interstitial porewater bacterial communities.

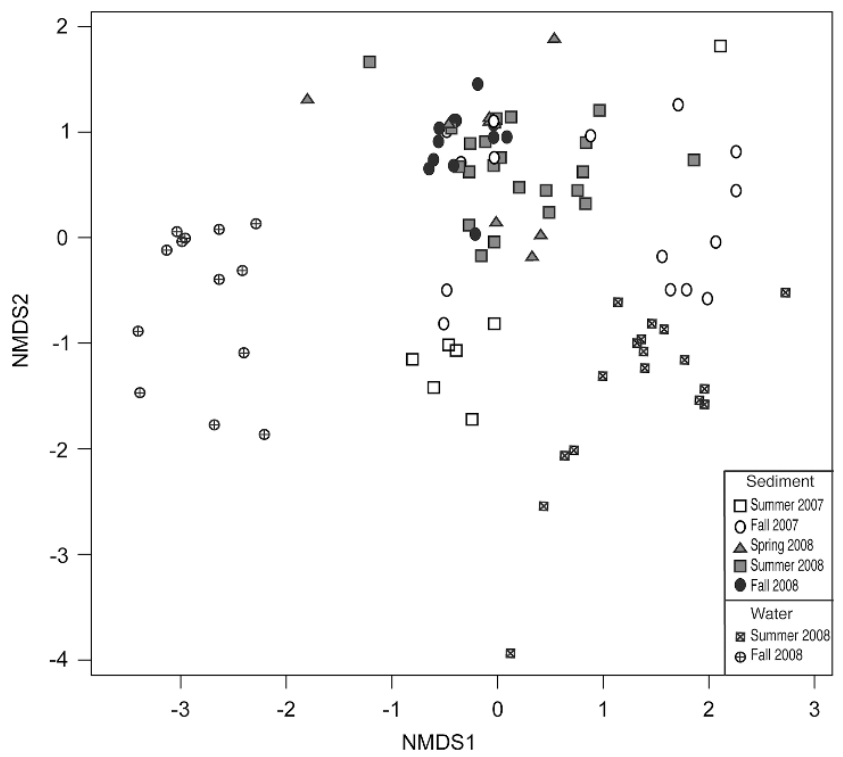

Figure 6 Scores from non-metric multidimensional scaling representing bacterial communities collected from hyporheic sediments, surface and interstitial water samples from all sampling seasons (final stress $=17.06$ ). Symbols that are close together on the plot indicate bacterial communities that are more similar than symbols that are further apart in multidimensional space. Indicated are sediment bacterial communities from the following seasons: Summer 2007 (white squares), Fall 2007 (white circles), Spring 2008 (grey triangles), Summer 2008 (grey squares) and Fall 2008 (black circles). Interstitial and surface waters are indicated as follows: Summer 2008 (square with crosshatch) and Fall 2008 (circle with cross-hatch). ANOSIM by sample type, $R=0.50, P=0.001$; ANOSIM by season, $R=0.06$, $P=0.019$.

\section{Bacterial community dynamics in intermittent} headwater streams

Bacterial communities varied significantly according to sample type (ANOSIM, $R=0.5, P=0.001$ ). Unsurprisingly, interstitial porewater samples showed the most variation in community composition. Along a shorter timescale (that is, summer and fall 2008 only), interstitial and surface water communities were highly dynamic during consecutive flooding and recovery periods (Figure 8). The stream rewetted in mid-June following heavy rainfall 
and slowly dried up into the fall. We sampled the flooding period from 10 June to 23 June, and sampled the recovery period on 11 September and 11 October. Overall, community diversity decreased over the course of flooding, with relatively few
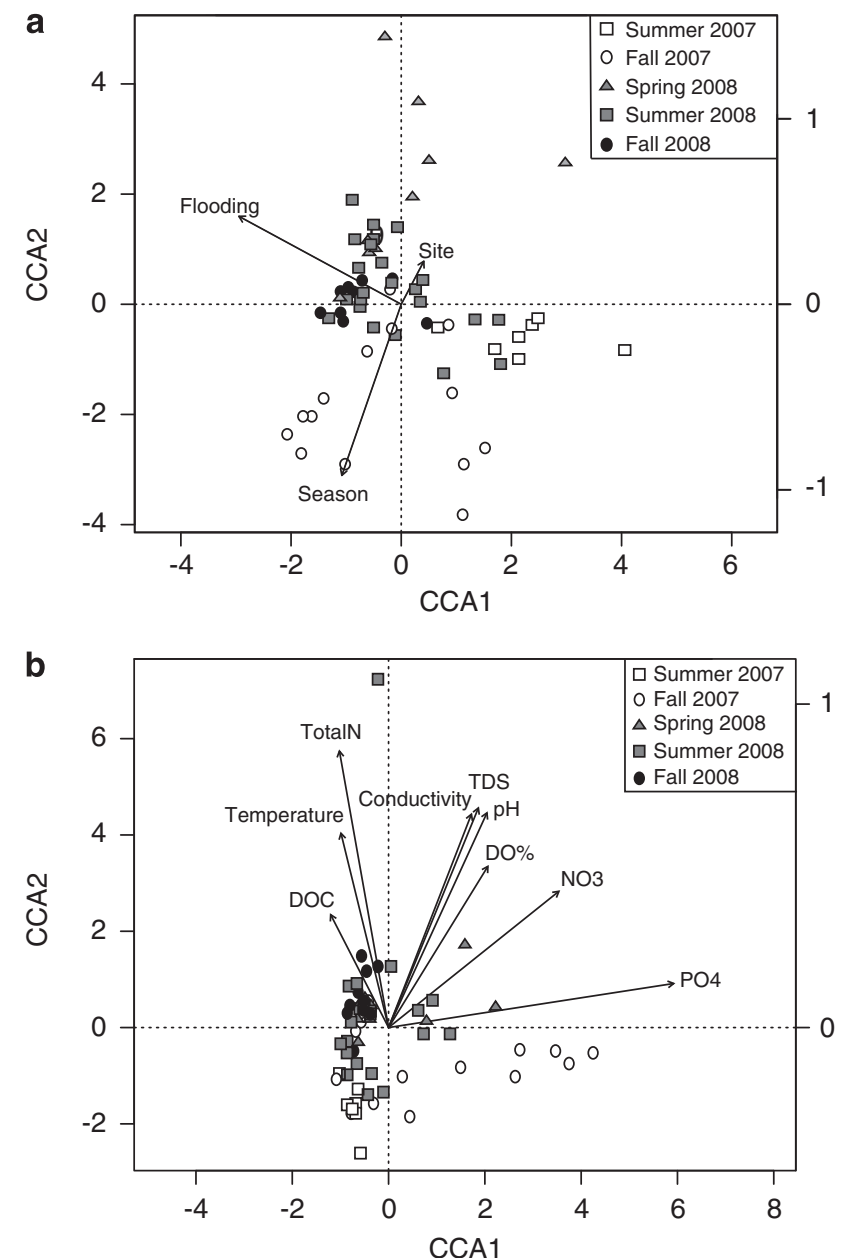

Figure 7 (a) Plot of CCA showing the relationship between sediment bacterial communities and environmental factors (flooding, site and season). (b) Plot showing CCA of sediment bacterial communities and seasonal physicochemistry (DOC concentration, DO dissolved oxygen concentration, temperature, TDS, total dissolved solids; conductivity, $\mathrm{NO}_{3}$, nitrate concentration; $\mathrm{PO}_{4}$, phosphate concentration; and TotalN, total nitrogen concentrations). Arrows indicate the direction and magnitude of each environmental or physicochemical factor associated with bacterial communities.

Figure 8 Bacterial OTU diversity in interstitial and surface water collected during the 2008 flooding event (See Figure 2 for plan view of streambed flooding): (a) 11 July, dry streambed; (b) 19 July, flooded streambed; (c) 23 July, flooded streambed; (d) 11 September, partially flooded; (e) 11 October, partially flooded. Individual bars represent OTU diversity as a proportion of the total population. Each colour represents a unique OTU. Note that bars of the same colour and relative position represent the same OTU across all locations and dates. Symbols associated with specific OTUs (For example, ${ }^{*},+, \bullet$ and $\approx$ ) indicate examples of OTUs that appear across multiple sites and dates.
OTUs dominating later samples at all depths (Figure 8). Certain OTUs increased in representation during the rewetting event. OTU richness in water samples showed a strong negative correlation with sampling date $\left(R^{2}=0.54, F=16.58, P<0.001\right)$.

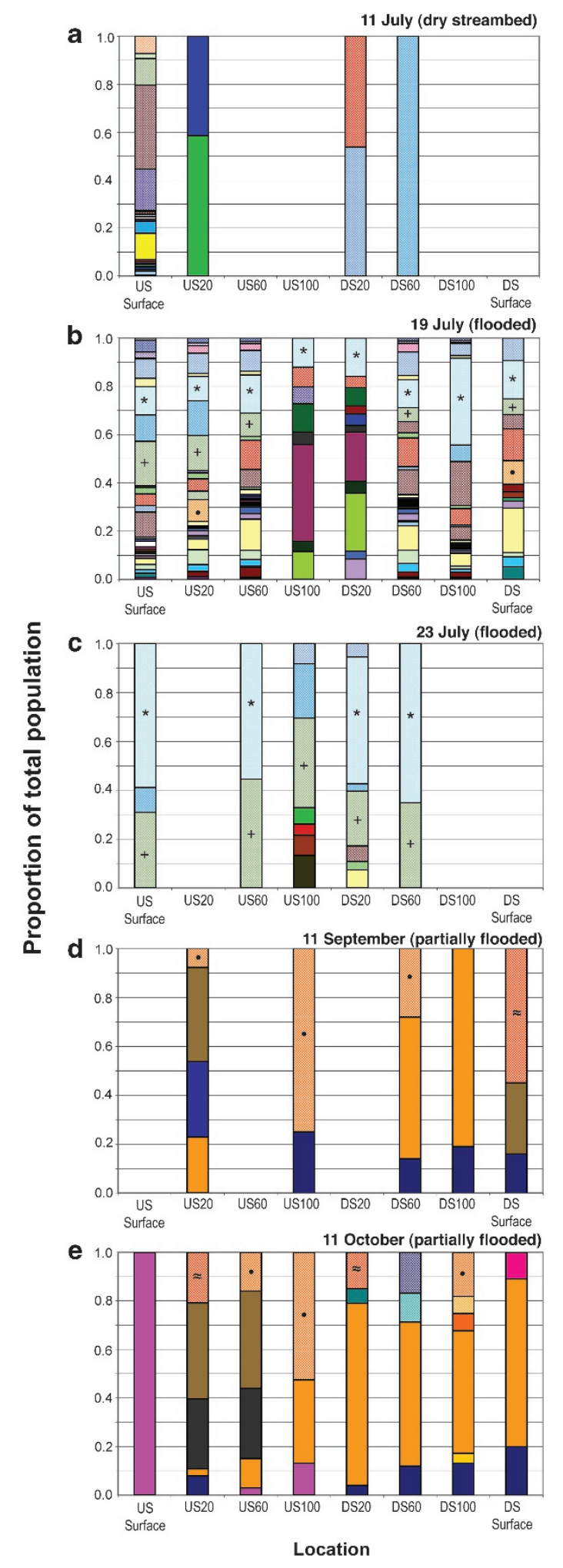


The OTUs were highest before flooding followed by an immediate decrease after flooding. For example, average number of OTUs before the flood averaged $13.5 \pm 7.0$ (19 June), OTUs in a few isolated pools at the surface varied considerably with $17.7 \pm 28$ OTUs (10 July), followed by a decrease in overall OTU number with $4.2 \pm 2.6$ (23 July). There was a strong inverse trend in OTU richness during flooding $\left(R^{2}=0.54, F=16.58, P<0.0001\right)$, whereby certain OTUs increased in abundance and dominated the flooded communities. Subsequently, we observed a weaker inverse correlation during the recovery period (July 23-October 10, $R^{2}=0.08$, $F=1.42, \quad P<0.0001)$. The OTUs most dominant during the rewetting event were not observed in any of the recovery communities, and OTU diversity did not return to pre-flooding levels. For example, at the US60 site, the number of OTUs present in the sample increased to 25 (19 June) and subsequently fell to 2 (23 July) during flooding, then remained at 2 during recovery (10 October).

\section{Discussion}

In these headwater systems, much of the interactions and biodiversity within the sediments are tightly coupled with above-ground biodiversity and ecosystem processes (Palmer et al., 2000). However, despite a wider recognition that bacteria represent a direct link between organic carbon and higher trophic consumers (Meyer, 1994), bacteria remain the least known component of stream food webs (Meyer et al., 2007). Bacterial communities were mostly discriminated between sediment and pore water, however, significant differences between season and flooding were also described. Communities did not appear to vary significantly with depth into the sediments or location (that is, US and DS). Whereas the sediment samples reflected longerterm bacterial community dynamics, interstitial pore water communities were more transient populations in the stream.

Here, fall bacterial communities in 2008 were strongly correlated with DOC concentrations (when the stream held water) than fall 2007 communities (when the stream was dry). Stream flooding events within a watershed can result in elevated DOC levels associated with flushing, throughfall, leaching and storage of DOC (Meyer and Tate, 1983). DOC levels were elevated in surface water although DOC levels did vary widely at the US location $(100 \mathrm{~cm})$. At the streambed surface, litterfall inputs and DOC leached from other sources likely accumulated on the streambed surface or in the surrounding watershed. This run-off into the stream also carried unique attached bacterial taxa into the hyporheic zone, which may include bacteria associated with lower molecular weight DOC (Sabater et al., 1993). At depth, DOC released from storage or particulate organic carbon in the sediments would therefore readily support bacterial communities. Therefore, a correlation in fall communities with DOC concentrations may also be reflective of higher rates of microbial activity among interstitial pore spaces.

Stream water intermittency influenced surface and porewater communities more than sediments, especially deeper into the hyporheic zone. Generally, bacterial OTU numbers were greatest among interstitial pore water samples, summer communities, and among surface and near-surface locations (for example, surface, $20 \mathrm{~cm}, 60 \mathrm{~cm}$ ). Among the pore water communities, OTU diversity varied widely across all sites and on very rapid time scales (Figure 8). The rapid change in OTU diversity in pore water communities across such rapid time scales (that is, days) has not been observed in other studies of natural systems. It is clear that some common taxa that appeared upon flooding became dominant within days yet do not persist later into the season. A plausible reason for such dynamic changes may be due to the influx of bacteria associated or attached to particulate matter carried from the surrounding watershed, precipitation and run-off (Fazi et al., 2008). As the stream was flowing during these summer and fall months, bacteria were likely transported downstream as most did not persist in the pore spaces, and only a moderate number of OTUs were found in the sediments.

Our findings suggest that OTUs represented bacteria that were native to either sediments or pore water, and not both. Based on the frequency of specific terminal-restriction fragment (T-RF) lengths generated using T-RFLP, nearly one in five bacterial taxa were found in both sediments and water $(19 \%$ of all OTUs), which suggest that a moderate number of bacteria may thrive under both drought and flood conditions. Using the $16 \mathrm{~S}$ rDNA fingerprint, it was not possible to tease apart the distribution of generalist and specialist taxa, however, testable hypotheses are proposed. In the case of interstitial bacteria, nutrients were limited during periods of low-flow. Hydrologic evidence suggests that once interstitial pore spaces become filled with water, patches would become connected and surface flow downstream would occur. At the streambed surface, bacteria were likely transported from several watershed sources during extreme flooding events (a deterministic process), and, during periods of lesssevere flooding and drought, the hyporheic zone may support random species sorting associated with the infiltration of water, nutrients and the creation of microhabitats in the sediments (Figure 1).

Efforts to identify the main T-RF lengths were made using web-based resources such as MiCA (microbial community analysis, http://mica.ibest. uidaho.edu/trflp.php; Shyu et al., 2007), which specialize in the analysis of $16 \mathrm{~S}$ and $18 \mathrm{~S}$ phylogenies, the identification of bacterial species was unsuccessful. For example, of the OTUs described and two restriction enzymes used in the present study, only one T-RF was identified using the online 
tools available. Universal $16 \mathrm{~S}$ primers were employed in this study, however, future studies may wish to consider other primers, such as those associated with specific ecosystem functions (for example, nitrogen fixing), and additional combinations of primers and restriction enzymes, clonal libraries and sequencing. To better understand the mechanisms that promote the establishment of hyporheic bacterial communities, further empirical testing and examination of the factors between generalist and specialist bacteria, and the exact sources of bacteria, is required.

\section{Linking hyporheic bacterial communities and stream intermittency to theoretical frameworks}

As empirical work for all stream taxa and types of intermittent systems are lacking, several theoretical frameworks have been proposed to explain community assembly and plausible patterns in biodiversity (Lake, 2000; Lepori and Malmqvist, 2007; Larned et al., 2010). Drawing on Lake's (2000) classification system of disturbance, patchiness and diversity in streams, flooding and drought events in this study can be considered either a pulse event (for example, in the case of single heavy precipitation events) or a press disturbance event (for example, periods drought) that resulted in a patchy distribution of nutrients and bacterial communities via connectivity in the sediments. Disturbance due to flooding represents a random, stochastic process in a stream but can also represent a deterministic process when flooding becomes severe, causing scouring of the streambed (Fowler and Death, 2001; Lepori and Malmqvist, 2007, 2009). It remains untested as to how such events would affect hyporheic microbes. The present study generated evidence that the hyporheic zone and bacterial communities here exhibited patterns in localized microbial diversity that may reflect source-sink relationships (that is, porewater and surface water communities as a source of new taxa), patchy mosaics in the sediments (that is, spatial differences in hyporheic bacterial diversity) and biogeochemical pulses triggered by the onset of surface flow (Larned et al., 2010). We compared OTUs to explore if bacteria were shaped by either deterministic or stochastic processes. As several taxa were ubiquitous across sample types and seasons, there is evidence that a portion of the community was suited to fluctuating physical conditions (that is, stochasticity). In contrast, site location was a significant correlate for spring communities in the dry year whereas season was associated with fall communities in the dry year, and several rare OTUs became concentrated in isolated pools at the stream surface (that is, determinism).

What are the implications of a small-scale study on an intermittent headwater stream to the larger river continuum? In southern Ontario, Canada, where our study was conducted, $86 \%$ of all head- water streams are intermittent (Williams, 2006). In this region, disturbance events are predicted to become more severe, and permanently flowing streams are thought likely to become increasingly intermittent (Magnuson et al., 1997). Despite how numerous intermittent headwater streams are within a watershed, only a few studies on their microbial communities have been conducted (Robson et al., 2008; Gaudes et al., 2009), and even fewer for transitional terrestrial-aquatic or aquatic-aquatic environments, like the hyporheic zone (Chafiq et al., 1999). We show that although microbial communities varied over small spatial and temporal scales, the patterns were significantly correlated with physical features of the watershed. Future work should assess the varying degrees of sediment saturation, the influence of groundwater and potential trophic interactions in the hyporheic zone. As intermittent headwater streams are the most numerous within a watershed, they are subjected to stressors like development of climate change that will have direct effects on hydrology. Bacterial community dynamics, such as those described here, will likely have implications to biodiversity and nutrient processing downstream along the river continuum.

\section{Acknowledgements}

We thank the anonymous reviewers whose comments improved the quality of this manuscript. We thank the Dewar family for their generous support and for providing unlimited access to their property for this study. We thank members of the Fulthorpe Microbial Ecology Lab and members of the Williams Lab for assistance. This project was funded by NSERC Canada (to DDW, CGS to CMF), the Sigma Xi Grant-in-Aid of Research (to CMF) and the University of Toronto Centre for Global Change Science (to PB and CMF).

\section{References}

Boulton AJ, Findlay S, Marmonier P, Stanley EH, Valett HM. (1998). The functional significance of the hyporheic zone in streams and rivers. Annu Rev Ecol Syst 29: 59-81.

Boulton AJ, Lake PS. (1990). The ecology of 2 intermittent streams in Victoria, Australia .1. Multivariate analyses of physicochemical features. Freshwater Biol 24: 123-141.

Boulton AJ, Lake PS. (1992). The ecology of 2 intermittent streams in Victoria, Australia .2. Comparisons of faunal composition between habitats, rivers and years. Freshwater Biol 27: 99-121.

Brunke M, Gonser T. (1997). The ecological significance of exchange processes between rivers and groundwater. Freshwater Biol 37: 1-33.

Chafiq M, Gibert J, Claret C. (1999). Interactions among sediments, organic matter, and microbial activity in the hyporheic zone of an intermittent stream. Can J Fish Aquat Sci 56: 487-495. 
Closs GP, Lake PS. (1994). Spatial and temporal variation in the structure of an intermittent-stream food-web. Ecol Monogr 64: 1-21.

Dekar MP, Magoulick DD, Huxel GR. (2009). Shifts in the trophic base of intermittent stream food webs. Hydrobiol 635: 263-277.

DiStefano RJ, Magoulick DD, Imhoff EM, Larson ER. (2009). Imperiled crayfishes use hyporheic zone during seasonal drying of an intermittent stream. J N Am Benthol Soc 28: 142-152.

Fazi S, Amalfitano S, Piccini C, Zoppini A, Puddu A, Pernthaler J. (2008). Colonization of overlaying water by bacteria from dry river sediments. Environ Microbiol 10: 2760-2772.

Febria CM, Fulthorpe RR, Williams DD. (2010). Characterizing seasonal changes in physicochemistry and bacterial community composition in hyporheic sediments. Hydrobiol 647: 113-126.

Feris K, Ramsey P, Frazar C, Moore JN, Gannon JE, Holben WE. (2003). Differences in hyporheic-zone microbial community structure along a heavy-metal contamination gradient. Appl Environ Microbiol 69: 5563-5573.

Findlay S, Sobczak WV. (2000). Microbial communities in hyporheic sediments. In: Jones JB, Mulholland PJ (eds). Streams and Ground Waters. Academic Press: New York, pp 287-306.

Fowler RT, Death RG. (2001). The effect of environmental stability on hyporheic community structure. Hydrobiol 445: 85-95.

Gaudes A, Artigas J, Romani AM, Sabater S, Munoz I. (2009). Contribution of microbial and invertebrate communities to leaf litter colonization in a Mediterranean stream. J N Am Benthol Soc 28: 34-43.

Gotelli NJ, Ellison AM. (2004). A Primer of Ecological Statistics. Sinauer Associates Inc: Sunderland, MA.

Hullar MAJ, Kaplan LA, Stahl DA. (2006). Recurring seasonal dynamics of microbial communities in stream habitats. Appl Environ Microbiol 72: 713-722.

Lake PS. (2000). Disturbance, patchiness, and diversity in streams. J N Am Benthol Soc 19: 573-592.

Larned ST, Datry T, Arscott DB, Tockner K. (2010). Emerging concepts in temporary-river ecology. Freshwater Biol 55: 717-738.

Lepori F, Malmqvist B. (2007). Predictable changes in trophic community structure along a spatial disturbance gradient in streams. Freshwater Biol 52: 2184-2195.

Lepori F, Malmqvist B. (2009). Deterministic control on community assembly peaks at intermediate levels of disturbance. Oikos 118: 471-479.

Lowell JL, Gordon N, Engstrom D, Stanford JA, Holben WE, Gannon JE. (2009). Habitat heterogeneity and associated microbial community structure in a smallscale floodplain hyporheic flow path. Microb Ecol 58: 611-620.

Magnuson JJ, Webster KE, Assel RA, Bowser CJ, Dillon PJ, Eaton JG et al. (1997). Potential effects of climate changes on aquatic systems: laurentian great lakes and precambrian shield region. Hydrol Proc 11: 825-871.

McCune B, Grace JB. (2002). Analysis of Ecological Communities, MjM Software Design, Gleneden Beach, Oregon.

Meyer JL. (1994). The microbial loop in flowing waters. Microb Ecol 28: 195-199.
Meyer JL, Strayer DL, Wallace JB, Eggert SL, Helfman GS, Leonard NE. (2007). The contribution of headwater streams to biodiversity in river networks. J Am Water Resour Assoc 43: 86-103.

Meyer JL, Tate CM. (1983). The effects of watershed disturbance on dissolved organic-carbon dynamics of a stream. Ecology 64: 33-44.

Naiman RJ, Décamps H, McClain ME. (2005). Riparia: Ecology, Conservation, and Management of Streamside Communities. Elsevier Academic Press: Amsterdam, Boston.

Oksanen J, Kindt R, Legendre P, O’Hara B, Simpson GL, Stevens $\mathrm{MHH}$ et al. (2009). Vegan: Community Ecology Package. R package version 2.9.2.http:// vegan.r-forge.r-project.org/.

Palmer MA, Covich AP, Lake S, Biro P, Brooks JJ, Cole J et al. (2000). Linkages between aquatic sediment biota and life above sediments as potential drivers of biodiversity and ecological processes. Bioscience 50: 1062-1075.

Ramette A. (2007). Multivariate analyses in microbial ecology. FEMS Microbiol Ecol 62: 142-160.

Richardson JS, Danehy RJ. (2007). A synthesis of the ecology of headwater streams and their riparian zones in temperate forests. Forest Sci 53: 131-147.

Robson BJ, Matthews TG, Lind PR, Thomas NA. (2008). Pathways for algal recolonization in seasonally-flowing streams. Freshwater Biol 53: 2385-2401.

Sabater F, Meyer JL, Edwards RT. (1993). Longitudinal patterns of dissolved organic-carbon concentration and suspended bacterial density along a blackwater river. Biogeochemistry 21: 73-93.

Shyu C, Soule T, Bent SJ, Foster JA, Forney LJ. (2007). MiCA: a web-based tool for the analysis of microbial communities based on terminal-restriction fragment length polymorphisms of $16 \mathrm{~S}$ and $18 \mathrm{~S}$ rRNA genes. Microb Ecol 53: 562-570.

Sliva L, Williams DD. (2005). Exploration of riffle-scale interactions between abiotic variables and microbial assemblages in the hyporheic zone. Can J Fish Aquat Sci 62: 276-290.

Storey RG, Fulthorpe RR, Williams DD. (1999). Perspectives and predictions on the microbial ecology of the hyporheic zone. Freshwater Biol 41: 119-130.

Vannote RL, Minshall GW, Cummins KW, Sedell JR, Cushing CE. (1980). River continuum concept. Can J Fish Aquat Sci 37: 130-137.

Williams DD. (1984). The hyporheic zone as a habitat for aquatic insects and associated arthropods. In: Resh VH, Rosenberg DM (eds). The Ecology of Aquatic Insects. Praeger: New York, pp 430-455.

Williams DD. (1989). Towards a biological and chemical definition of the hyporheic zone in 2 Canadian rivers. Freshwater Biol 22: 189-208.

Williams DD. (1993). Nutrient and flow vector dynamics at the hyporheic groundwater interface and their effects on the interstitial fauna, Hydrobiologia 251: 185-198.

Williams DD. (2006). The Biology of Temporary Waters. Oxford University Press: Oxford.

Williams DD, Febria CM, Wong JCY. (2010). Ecotonal and other properties of the hyporheic zone. Fund Appl Limnol 176: 349-364.

Williams DD, Hynes HBN. (1974). Occurrence of benthos deep in substratum of a stream. Freshwater Biol 4: $233-255$.

Supplementary Information accompanies the paper on The ISME Journal website (http://www.nature.com/ismej) 